\title{
Game Edukasi Mitigasi Bencana Kebakaran Berbasis Android
}

\author{
Siti Martatiani Muyasaroh \\ Fakultas Komunikasi dan Informatika \\ Universitas Muhammadiyah Surakarta \\ Surakarta, Indonesia \\ E-mail : Martatiani55@gmail.com
}

\author{
Endah Sudarmilah \\ Program Studi Informatika, FKI \\ Universitas Muhammadiyah Surakarta \\ Surakarta, Indonesia \\ E-mail : Endah.sudarmilah@ums.ac.id
}

\begin{abstract}
Abstrak Kebakaran sering terjadi karena merupakan peristiwa yang terjadi akibat api yang membesar, penyebabnya bisa karna faktor manusia, teknis atau bencana alam sebagai warga Indonesia harus mampu mengurangi resiko terjadinya bencana. Salah satunya yaitu dari pendidikan dasar yang dimulai dari anak-anak bisa menjadi contoh yang baik untuk menanggulangi bencana. Tujuan dari penulis adalah membangun game edukasi mitigasi kebakaran berbasis android yang memenuhi syarat dalam edukasi pada anak usia dini untuk mengurangi resiko terjadinya kebakaran. Metode yang digunakan penulis yaitu menggunakan metode System Development life Cycle atau SDLC yang menggunakan model Waterfall. Edugame mitigasi bencana kebakaran yang berbasis android dengan nama Boim Sang Penakluk Api yang dibuat dengan Construct 2 dapat menambah pengetahuan tentang mitigasi bencana kebakaran. Serta berdasarkan dengan pengujian dengan menggunakan SUS (System Usability Scale) aplikasi berjalan tanpa ada kesalahan.
\end{abstract}

Kata kunci : Construct 2, Edugame, Mitigasi, Kebakaran

\section{Pendahuluan}

Kebakaran terjadi akibat api yang membesar, penyebabnya pun beragam karna faktor manusia, teknis atau bencana alam. Data dari Badan Nasional Penanggulangan Bencara (BNPB) menunjukan bahwa kebakaran yang terjadi di Indonesia pada tahun 2018 mencapai 38 kejadian kebakaran hutan dan lahan walau tidak menyebabkan korban jiwa namun kerugian juga dirasakan oleh penduduk sekitar. Hal ini menunjukan bahwa kebakaran menjadi salah satu bencana yang harus diwaspadai. Dampak dari kebakaran yang biasa dirasakan manusia berupa kerugian ekonomis yaitu hilangnya manfaat hutan yang biasa digunakan manusia untuk memenuhi kebutuhannya. [1]

Undang-Undang Republik Indonesia Nomor 24 Tahun 2007 Tentang Penanggulangan Bencana sudah dijelaskan, maka kita sebagai warga Indonesia harus mampu mengurangi resiko terjadinya bencana. Salah satunya yaitu dari pendidikan dasar yang dimulai dari anak-anak bisa menjadi contoh yang baik untuk menanggulangi bencana, diantaranya melalui game edukasi.

Game biasa digunakan sebagai sarana untuk mengisi waktu luang dan melepas penat. [2] Game biasanya dibuat untuk hiburan penghilang stress dan juga dibuat untuk pendidikan atau edukasi pada anak yang ingin belajar dengan tidak merasakan rasa bosan pada suatu hal yang ingin dipelajari. Ada yang mengira bahwa permainan itu identik dengan kekerasan, kebiasaan buruk dan memiliki banyak hal negatif dalam masyarakat kita. [3]. Pada umumnya game juga melibatkan stimulasi mental atau fisik serta yang dapat mengembangkan kreatifitas pada anak sebagai bahan latihan. Game edukasi berfungsi untuk menumbuhkan pengetahuan, keterampilan, kecerdasan, emosi, dan nilai-nilai sikap. [4]

Construct 2 merupakan sebuah aplikasi yang digunakan untuk membuat game 2 dimensi berbasis HTML 5 [5]. Game yang dibangun dengan menggunakan construct lebih menggunakan logika daripada menulis kode-kode pemrograman yang banyak. Game dirancang agar murid menjadi sadar dan termotivasi untuk belajar dan sebagai penghibur dari game yang dimaksud [6].

Tujuan dari penulis adalah membangun game edukasi mitigasi kebakaran berbasis android yang memenuhi syarat dalam edukasi pada anak usia dini untuk mengurangi resiko terjadinya kebakaran.

\section{METODE}

Metode yang digunakan penulis yaitu menggunakan metode System Development life Cycle atau SDLC yang menggunakan model Waterfall. Model Waterfall SDLC adalah perangkat lunak sekuensial proses pengembangan di mana kemajuan dianggap sebagai mengalir semakin ke bawah (mirip dengan air terjun) [7] seperti pada gambar 1 .

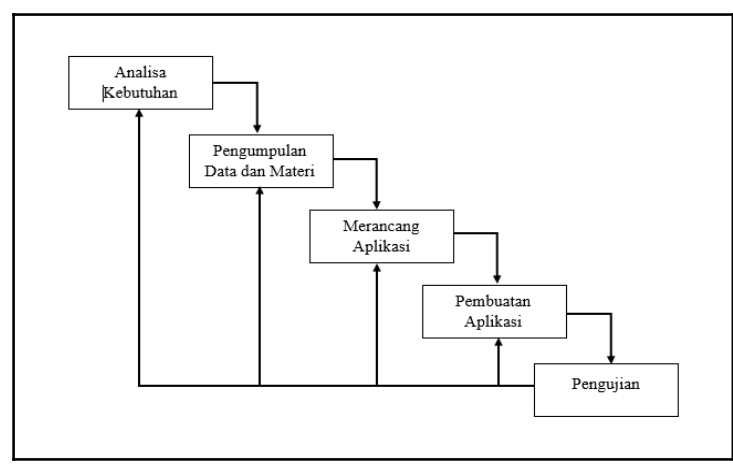

Gambar 1. Model Waterfall SDLC 
Tahap-tahap pembuatan game edukasi sebagai berikut :

\section{A. Analisa Kebutuhan}

Tabel 1. Alat dan Bahan

\begin{tabular}{|c|c|}
\hline Software & Hardware \\
\hline $\begin{array}{c}\text { Coreldraw X7 untuk membuat } \\
\text { desain objek 2D }\end{array}$ & Smart Phone Xiaomi MI A4 \\
\hline $\begin{array}{c}\text { Adobe Ilustration untuk } \\
\text { membuat desain objek 2D }\end{array}$ & Flashdisk 20 GB \\
\hline $\begin{array}{c}\text { Adobe Premier untuk mengedit } \\
\text { sound }\end{array}$ & Laptop ASUS A455LD-WX110D \\
\hline $\begin{array}{c}\text { Construct } 2 \text { untuk membuat } \\
\text { game }\end{array}$ & \\
\hline $\begin{array}{c}\text { Windows } 8.1 \text { sebagai sistem } \\
\text { operasi }\end{array}$ & \\
\hline $\begin{array}{c}\text { Phonegap untuk mengeksport } \\
\text { file ke apk }\end{array}$ & \\
\hline
\end{tabular}

\section{B. Pengumpulan Data dan Materi}

Sumber data untuk menerapkan ide pada perancangan game edukasi mitigasi kebakaran dengan review kajian pustaka dan jurnal untuk panduan perancangan aplikasi.

\section{Perancangan Aplikasi}

\section{1). Story Line}

Game edukasi mitigasi bencana kebakaran dengan nama "Boim Sang Penakluk Api" adalah game edukasi yang dibuat untuk pembelajaran anak umur 10-12 tahun atau kelas 5 sampai 6 SD. Game ini mengajarkan pada anak tentang penyelamatan korban bencana kebakaran. Hal-hal yang diajarkan antara lain seperti tindakan apa yang harus dilakukan saat terjadi kebakaran, apa yang menyebabkan kebakaran, dan bagaimana meminimalisir terjadinya kebakaran. Permainan terdiri dari 3 level, yaitu level pertama pemain harus menyelamatkan makhluk hidup yang ditemuinya dan harus menghindari api yang membakar barang-barang serta mengumpulkan koin, level kedua pemain harus menghindari api yang jatuh dari atas, mengumpulkan koin dan juga mengumpulkan barang-barang yang diperintahkan, dan level ketiga pemain harus mampu memadamkan api serta mengumpulkan koin dan menghindari api.

\section{2). Story Board}

Story board merupakan gambaran inti dari aplikasi atau program yang dirangkai untuk selanjutnya disusun menjadi acuan pembuatan program atau aplikasi.

\section{Pembuatan Aplikasi}

Untuk membuat aplikasi menggunakan :

\section{1). Software}

a). Coreldraw $X 7$ untuk membuat desain objek $2 \mathrm{D}$

b). Adobe Ilustration untuk membuat desain objek 2D

c). Adobe Premier untuk mengedit sound

d). Construct 2 untuk membuat game

e). Windows 8.1 sebagai sistem operasi

f). Phonegap untuk mengeksport file ke apk

\section{2). Hardware}
a). Smart Phone Xiaomi MI A4
b). Flashdisk $20 \mathrm{~GB}$
d). Laptop ASUS A455LD-WX110D

\section{3). Asset}

Asset yang terdapat dalam aplikasi dibuat sendiri oleh penulis selain itu juga mengambil beberapa asset dari freepik.com, bevouliin.com dan kenney.com sebagai asset objek dan terdapat pula asset sound yang diambil dari zapsplat.com.

Tabel 2. Story board game Boim Sang Penakluk Api

\begin{tabular}{|c|c|c|}
\hline No & Bagian Game & Keterangan \\
\hline 1 & & $\begin{array}{l}\text { Tampilan Loading bar pada game } \\
\text { yang tampil ada urutan pertama } \\
\text { dalam game }\end{array}$ \\
\hline 2 & $\begin{array}{l}\text { (2) (D) (7) } \\
\text { (41) (1) ( })\end{array}$ & $\begin{array}{l}\text { Menu utama game yang terdiri } \\
\text { dari } 6 \text { tombol tombol yaitu tombol } \\
\text { play, help, information, music, } \\
\text { sound dan exit. }\end{array}$ \\
\hline 3 & Penycbab Kcbakaran & $\begin{array}{l}\text { Tombol Help ditekan maka akan } \\
\text { muncul pop up yang berisi } \\
\text { informasi penyebab kebakaran } \\
\text { game seperti ada gambar }\end{array}$ \\
\hline 4 & Tentang Game & $\begin{array}{l}\text { Apabila tombol Information } \\
\text { ditekan maka akan muncul pop up } \\
\text { yang berisi informasi tentang } \\
\text { game seperti pada gambar }\end{array}$ \\
\hline 5 & (D) & $\begin{array}{l}\text { Untuk tombol Play apabila } \\
\text { ditekan akan menuju ke halaman } \\
\text { intro permainan yang kemudian } \\
\text { menuju halaman level }\end{array}$ \\
\hline 6 & $\diamond$ & $\begin{array}{l}\text { Halaman level dalam permainan } \\
\text { terdiri dari } 3 \text { tobol yang } \\
\text { menunjukan informasi tombol } \\
\text { tersebut. }\end{array}$ \\
\hline 7 & 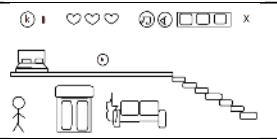 & $\begin{array}{l}\text { Untuk level pertama pemain } \\
\text { memiliki misi menemukan } \\
\text { makhluk hidup }\end{array}$ \\
\hline 8 & 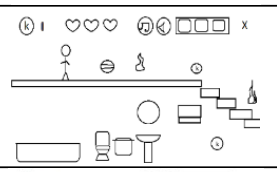 & $\begin{array}{l}\text { Level kedua pemain harus } \\
\text { menemukan barang-barang yang } \\
\text { bisa digunakan } \\
\begin{array}{l}\text { menyelamatlkan diri } \\
\text { kebakaran }\end{array} \\
\end{array}$ \\
\hline 9 & 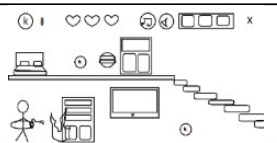 & $\begin{array}{l}\text { Level ketiga pemain harus } \\
\text { memadamkan api yang membakar } \\
\text { barang-barang }\end{array}$ \\
\hline 10 & $\widehat{\sqrt{g}}^{9}$ & $\begin{array}{l}\text { Apabila bisa melewati level } 3 \\
\text { maka akan menuju ke halaman } \\
\text { Winner selanjutnya akan muncul } \\
\text { pop up }\end{array}$ \\
\hline
\end{tabular}

\section{E. Pengujian}

Pengujian dilakukan setelah game selesai dibuat. Pengujian dilakukan dengan uji black box.

\section{HASIL DAN PEMBAHASAN}

\section{A. Hasil Pembahasan}

Penelitian ini menghasilkan game edukasi mitigasi bencana kebakaran dengan objek anak kelas 4-6 SD. Game edukasi ini berbasis android sehinggan mudah digunakan sebagai media pembelajaran 


\section{1). Halaman Awal Game Edukasi}

Halaman ini terdiri dari tampilan loading sebagai awal untuk masuk ke aplikasi

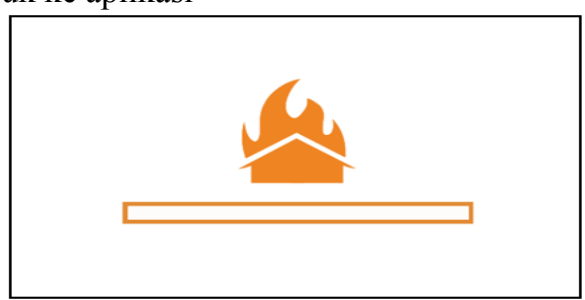

Gambar 2. Halaman Loading

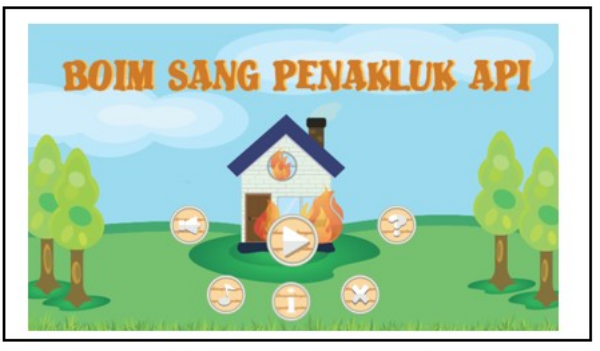

Gambar 3. Menu Utama

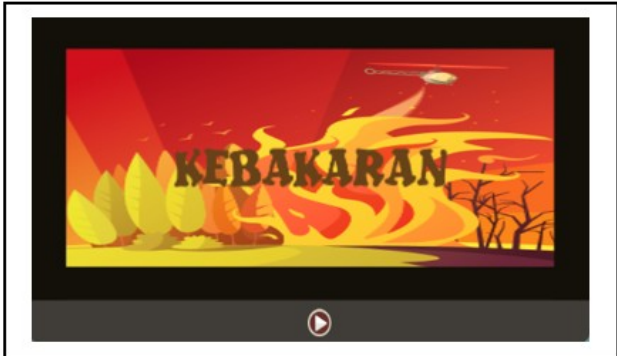

Gambar 4. Halaman Intro

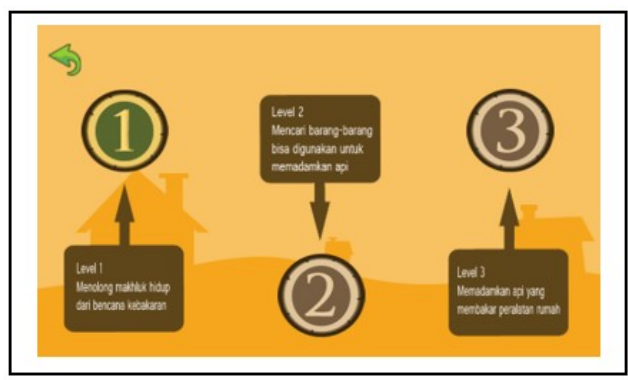

Gambar 5. Halaman Level

Halaman menu utama seperti pada gambar 3 terdapat 6 tombol yaitu tombol play untuk masuk pada halaman intro, help untuk masuk pada informasi penyebab kebakaran, information untuk masuk ke informasi tentang game, music untuk mengatur musik, sound untuk mengatur suara dan exit untuk keluar dari game. Pada halaman intro terdapat 1 tombol yaitu tombol play untuk masuk halaman levelseerti pada gambar 4. Pada halaman level terdapat 4 tombol yaitu tombol 1 untuk masuk level 1, 2 untuk masuk level 2, 3 untuk masuk level 3 dan back untuk kembali ke menu utama seperti pada gambar 5 .

\section{2). Halaman Permainan}

\section{a). Level 1}

Pada tampilan level 1 terdapat 3 tombol yaitu tombol exit, music dan sound yang memiliki misi mengumpulkan koin dan menyelamatkan hewan-hewan yang terjebak dalam kebakaran.

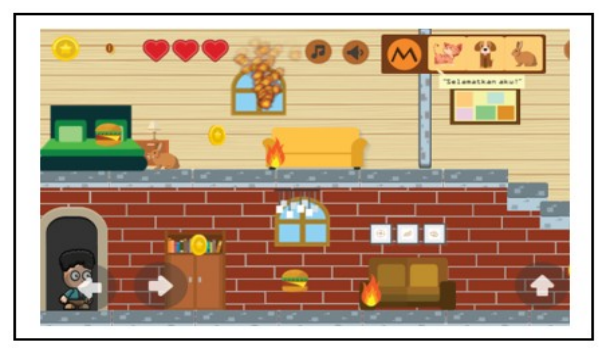

Gambar 6. Level 1

\section{b). Level 2}

Pada tampilan level 2 terdapat 3 tombol yaitu tombol exit, music dan sound yang memiliki misi mengumpulkan koin dan mencari barang-barang yang bisa digunakan untuk memadamkan api

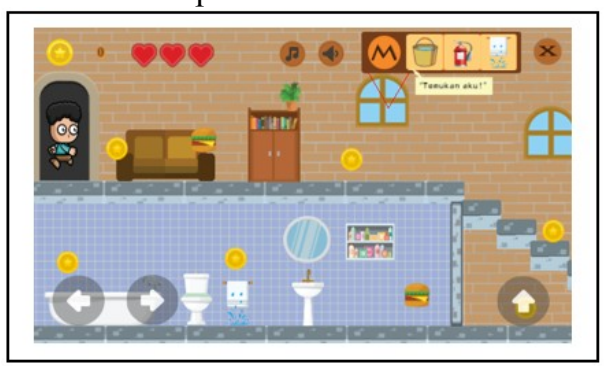

Gambar 7. Level 2

\section{c). Level 3}

Pada tampilan level 3 terdapat 3 tombol yaitu tombol exit, music dan sound yang memiliki misi mengumpulkan koin dan memadamkan api yang membakar barang-barang

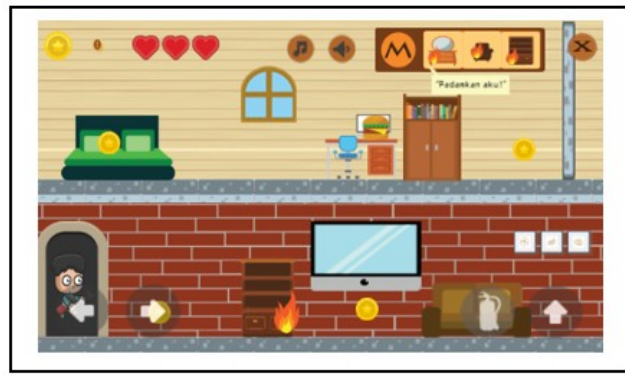

Gambar 8. Level 3

\section{d). Halaman Winner}

Pada tampilan halaman winner terdapat 1 tombol yaitu tombol kembali saat player tampil setelah melewati level 3

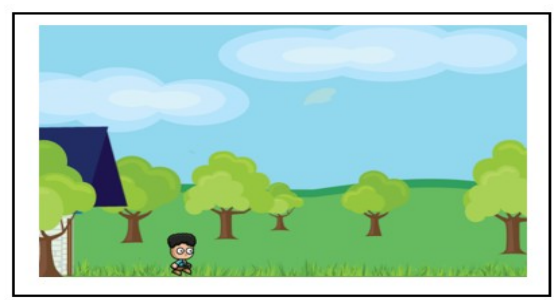

Gambar 9. Halaman Winner

\section{B. Pembahasan Hasil Penelitian}

Pengujian penelitian dilakukan pada tanggal 25/03/2019 yang bertempat di SD $\mathrm{N}$ Pabelan 2 Kartasura dengan mendemokan game edukasi mitigasi kebakaran yang berbasis android pada kelas V. Sistem penilaian yang digunakan yaitu menggunakan kuisioner. Rumus perhitungan menggunakan 
rumus SUS (System Usability Scale). Untuk menghitung skor SUS, pertama kontribusi skor dari setiap item dijumlahkan. kontribusi skor setiap item akan berkisar dari 0 sampai 4. Untuk item P1, P3, P5, P7, dan P9 kontribusi skor adalah posisi skala dikurangi 1. Untuk item P2, P4, P6, P8 dan P10, kontribusi adalah 5 dikurangi posisi skala. Kemudian dikalikan nilai sebesar 2,5 untuk memperoleh nilai keseluruhan SU. (Skor SUS memiliki nilai antara 0 sampai 100)[8].

Tabel 3. Perhitungan dengan rumus SUS

\begin{tabular}{|c|c|c|c|c|c|c|c|c|c|c|c|c|}
\hline \multirow[b]{2}{*}{ No } & \multicolumn{10}{|c|}{ Butir Pertanyaan } & \multirow[b]{2}{*}{ Total } & \multirow{2}{*}{$\begin{array}{l}\text { SUS Score } \\
(\text { Total *2.5) }\end{array}$} \\
\hline & $\begin{array}{l}\mathbf{P} \\
\mathbf{1}\end{array}$ & $\begin{array}{l}\mathbf{P} \\
2\end{array}$ & $\begin{array}{l}\mathbf{P} \\
3\end{array}$ & $\begin{array}{l}P \\
4\end{array}$ & $\begin{array}{l}\mathbf{P} \\
5\end{array}$ & $\begin{array}{l}P \\
6\end{array}$ & $\begin{array}{l}\mathbf{P} \\
7\end{array}$ & $\begin{array}{l}\mathbf{P} \\
\mathbf{8}\end{array}$ & $\begin{array}{l}\mathbf{P} \\
9\end{array}$ & $\begin{array}{c}\text { P1 } \\
\text { 0 }\end{array}$ & & \\
\hline 1 & 4 & 4 & 4 & 4 & 4 & 4 & 3 & 4 & 4 & 3 & 38 & 95 \\
\hline 2 & 3 & 3 & 3 & 3 & 3 & 3 & 1 & 3 & 3 & 0 & 25 & 62,5 \\
\hline 3 & 4 & 2 & 3 & 1 & 3 & 3 & 3 & 2 & 3 & 1 & 25 & 62,5 \\
\hline 4 & 4 & 3 & 4 & 3 & 4 & 3 & 4 & 4 & 1 & 3 & 33 & 82,5 \\
\hline 5 & 3 & 2 & 3 & 3 & 3 & 1 & 3 & 1 & 3 & 1 & 23 & 57,5 \\
\hline 6 & 4 & 4 & 4 & 4 & 4 & 4 & 4 & 4 & 4 & 0 & 36 & 90 \\
\hline 7 & 3 & 0 & 2 & 3 & 4 & 2 & 4 & 4 & 2 & 0 & 24 & 60 \\
\hline 8 & 3 & 3 & 4 & 4 & 3 & 4 & 3 & 3 & 4 & 1 & 32 & 80 \\
\hline 9 & 3 & 3 & 3 & 3 & 3 & 3 & 4 & 4 & 3 & 0 & 29 & 72,5 \\
\hline 10 & 3 & 3 & 3 & 3 & 3 & 2 & 3 & 3 & 2 & 2 & 27 & 67,5 \\
\hline 11 & 4 & 3 & 3 & 1 & 4 & 3 & 3 & 3 & 3 & 0 & 27 & 67,5 \\
\hline 12 & 4 & 4 & 4 & 3 & 4 & 4 & 2 & 4 & 4 & 3 & 36 & 90 \\
\hline 13 & 4 & 4 & 4 & 3 & 1 & 4 & 4 & 4 & 4 & 3 & 35 & 87,5 \\
\hline 14 & 4 & 4 & 4 & 4 & 4 & 4 & 4 & 4 & 4 & 4 & 40 & 100 \\
\hline 15 & 3 & 3 & 2 & 4 & 2 & 4 & 3 & 3 & 4 & 2 & 30 & 75 \\
\hline 16 & 3 & 3 & 3 & 1 & 3 & 3 & 3 & 3 & 3 & 1 & 26 & 65 \\
\hline 17 & 4 & 2 & 4 & 1 & 4 & 2 & 4 & 2 & 4 & 1 & 28 & 70 \\
\hline 18 & 4 & 3 & 3 & 3 & 3 & 4 & 3 & 4 & 3 & 4 & 34 & 85 \\
\hline 19 & 4 & 3 & 3 & 3 & 1 & 3 & 1 & 3 & 3 & 3 & 27 & 67,5 \\
\hline 20 & 4 & 4 & 4 & 1 & 4 & 4 & 4 & 4 & 2 & 0 & 31 & 77,5 \\
\hline 21 & 4 & 2 & 4 & 1 & 4 & 2 & 3 & 0 & 4 & 1 & 25 & 62,5 \\
\hline 22 & 4 & 4 & 4 & 4 & 4 & 4 & 4 & 3 & 4 & 3 & 38 & 95 \\
\hline 23 & 4 & 4 & 4 & 4 & 4 & 4 & 4 & 4 & 0 & 4 & 36 & 90 \\
\hline 24 & 4 & 4 & 4 & 3 & 4 & 4 & 3 & 4 & 4 & 3 & 37 & 92,5 \\
\hline 25 & 3 & 2 & 2 & 1 & 3 & 2 & 2 & 1 & 3 & 1 & 20 & 50 \\
\hline 26 & 4 & 3 & 3 & 2 & 4 & 3 & 3 & 3 & 3 & 3 & 31 & 77,5 \\
\hline 27 & 4 & 4 & 4 & 1 & 3 & 3 & 3 & 3 & 4 & 1 & 30 & 75 \\
\hline 28 & 4 & 3 & 3 & 1 & 2 & 2 & 3 & 2 & 3 & 1 & 24 & 60 \\
\hline 29 & 3 & 3 & 3 & 2 & 3 & 3 & 3 & 1 & 3 & 1 & 25 & 62,5 \\
\hline 30 & 3 & 3 & 3 & 3 & 3 & 3 & 1 & 3 & 3 & 0 & 25 & 62,5 \\
\hline \multicolumn{12}{|c|}{ Total } & 2242,5 \\
\hline
\end{tabular}

Tabel 4 Perhitungan dengan menggunakan rumus SUS mendapatkan total hasil 2242,5

\section{Keterangan Kode :}

P1 : Aplikasi sangat disukai dan akan memainkanya berkalikali

P2 : Aplikasi terlalu rumit untuk dimainkan

P3 : Aplikasi mudah untuk digunakan

P4 : Membutuhkan bantuan orang lain dalam memainkan aplikasi

P5 : Bagian-bagian dari aplikasi dapat dimainkan dengan baik

P6 : Cara bermain aplikasi membingungkan

P7 : Orang lain akan belajar dan bermain aplikasi dengan cepat

P8 : Aplikasi tidak praktis

P9 : Bisa memainkan aplikasi ini

P10 : Perlu belajar banyak untuk dapat memainkan aplikasi

Keterangan Skor :

1 : Sangat Tidak Setuju

2 : Tidak Setuju

3 : Ragu

4 : Setuju

5 : Setuju Sekali

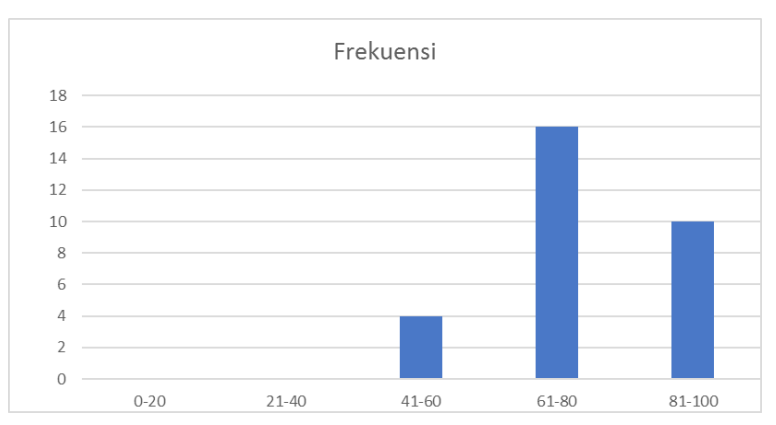

Gambar 10. Grafik perhitungan dengan rumus SUS

Rumus Perhitungan nilai rata-rata menggunakan persamaan:

$$
\text { Nilai rata }- \text { rata }=\sum_{i=1}^{\pi} \frac{x_{i}}{N}
$$

$x_{i}$ : Nilai Skor Responden

$N$ : Jumlah Responden

Maka:

Nilai rata-rata $=\frac{2242,5}{30}=74,75$

Selanjutnya mengukur hasil rata-rata dengan menggunakan skala interval sebagai berikut :

Angka 0-20: Sangat Buruk

Angka 21 - 40 : Buruk

Angka $41-60$ : Cukup

Angka $61-80$ : Baik

Angka 81 - 100 : Sangat Baik

Dari hasil tersebut maka dapat ditentukan bahwa nilai 74,75 berada diantara kriteria nilai 61 - 80 maka dinyatakan baik berjalan tanpa ada kesalahan.

\section{KESIMPULAN}

Hasil kesimpulan dari penelitian ini adalah edugame mitigasi bencana kebakaran yang berbasis android dengan nama Boim Sang Penakluk Api yang dibuat dengan Construct 2 dapat menambah pengetahuan tentang mitigasi bencana kebakaran. Berdasarkan uji usabilitas dengan menggunakan perhitungan SUS maka game ini dapat dimainkan oleh anak umur 10-12 tahun atau kelas 5-6 SD.

\section{DAFTAR PUSTAKA}

[1] F. Rasyid, "Permasalahan dan Dampak Kebakaran Hutan," J. Lingk. Widyaiswara, no. 4, pp. 47-59, 2014.

[2] M. S. Khairy, D. Herumurti, and I. Kuswardayan, "Analisis Pengaruh Penggunaan Game Edukasi pada Penguasaan Kosakata Bahasa Asing dengan Studi Kasus Game Edukasi Bahasa Arab," J. Ilmu Komput. dan Inform., vol. II, no. 2, pp. 42-48, 2016.

[3] S. Warnars, "Game Information System," Int. J. Comput. Sci. Inf. Technol., vol. 2, no. 3, pp. 135-148, 
2010.

[4] B. Darmanto and E. Sudarmilah, "Game Edukasi Dampak Pergaulan Bebas,” J. PROtek, vol. 3, no. 2, 2016.

[5] E. Sudarmilah and D. I. Nurrahim, "EduGame Sejarah Islam Masuk Indonesia," J. PROtek, vol. 3, no. 2, 2016.

[6] C. B. S. Hansen and T. Bjoerner, "Designing an Educational Game: Design Principles from a Holistic Perspective," Int. J. Learn., vol. 17, no. 10, 2010.

[7] Y. Bassil, "A Simulation Model for the Waterfall Software Development Life Cycle," Int. J. Eng. Technol., vol. 2, no. 5, 2012.

[8] J. Brooke, SUS - A quick and dirty usability scale. 1996. 